\title{
Voluntary exercise and testosterone therapy caused increase in percentage of Myh6 and expression of oxidative stress marker Cybb in left ventricles of rats Nárast percentuálneho zastúpenia Myh6 bol sprevádzaný nárastom expresie markera oxidačného stresu Cybb v lavých komorách potkanov medikovaných testosterónom
}

\author{
Comenius University in Bratislava, \\ Faculty of Pharmacy, \\ Department of Pharmacology and Toxicology, \\ Bratislava, Slovak Republic
}

Univerzita Komenského v Bratislave,

Farmaceutická fakulta

Katedra farmakológie a toxikológie

Bratislava, Slovenská republika

Received 24 June, 2016, accepted 20 July, 2016

Abstract Aim: The aim of this study is to identify a possible damage to heart ventricles caused by supraphysiological doses of testosterone, voluntary physical activity or their combination.

Methods: In the 8-week long experiment, 10-12 weeks old male Wistar rats were administered testosterone depot in dose of 100 $\mathrm{mg} / \mathrm{kg}(T E S, \mathrm{n}=15)$ or vehiculum (CON, $\mathrm{n}=12$ ) once a week subcutaneously. Next groups injected with testosterone (SPOTES, $\mathrm{n}=12$ ) or vehiculum (SPO, $\mathrm{n}=12$ ) were running in exercise wheels ad libitum. Gene expressions in left and right ventricles of the heart were measured by quantitative reverse transcription polymerase chain reaction method.

Results:In left ventricles of the testosterone groups, we observed a mild but significant increase in the percentage of Myh6 myosin heavy chain isoform and higher expression of NADPH oxidase subunit Cybb (*p $<0.05)$.

Conclusions:Testosterone affected the expression of genes related to contractile apparatus and oxidative stress in the left ventricle but not in right ventricle of the heart of rats. The observed level of physical activity did not have a compelling effect on the expression of measured genes.

Slovak Ciele: Ciel’om tejto práce je identifikovat’ možné poškodenie komôr myokardu vplyvom vysokých dávok testosterónu, nenútenej abstract fyzickej aktivity, alebo ich kombinácie.

Metódy: Samcom potkanov kmeňa Wistar vo veku 10-12 týždňov bol po dobu 8 týždňov 1x týždenne s.c. aplikovaný depot testosterónu v dávke $100 \mathrm{mg} / \mathrm{kg}(T E S, n=15)$ alebo vehikulum $(C O N, n=12)$. Skupinám s aplikovaným testosterónom (SPOTES, $\mathrm{n}=12$ ) alebo vehikulom (SPO, $\mathrm{n}=12$ ) bolo umožnené behat' v závesnom koliesku ad libitum. V myokarde lavých a pravých komôr srdca boli metódou RT-qPCR stanovené génové expresie.

Výsledky: V lavých komorách testosterónových skupín bol pozorovaný mierny, ale signifikantný nárast percentuálneho zastúpenia izoformy t’ažkých retazcov myozínu Myh6 a vyššia expresia podjednotky NADPH oxidázy Cybb (*p<0.05).

Záver: Testosterón ovplyvnil expresiu génov súvisiacich s kontraktilným aparátom a oxidačným stresom v lavej, ale nie v pravej komore srdca potkanov. Pozorovaná miera fyzickej aktivity nemala významný vplyv na expresiu sledovaných génov.

Keywords Testosterone-Physical activity-Heart ventricles-Oxidative stress-Myosin heavy chains

Klúčové testosterón-fyzická aktivita-srdcové komory-oxidačný stres - t’ažké retazce myozínu

slová:

\section{INTRODUCTION}

Abuse of anabolic steroids has been linked to a variety of cardiovascular side effects accompanied by elevated oxidative stress markers (Emer et al., 2016). Elevated testosterone concentrations on molecular level can induce cardiomyocyte hypertrophy (Altamirano et al., 2009). Cardioprotective effects of testosterone replacement therapy include improved ejection fraction and heart rate variability in orchiectomised rats (Pongkan et al., 2015) and improvements in exercise capacity and symptoms in men with heart failure (Pugh et al., 2004). Exercise affects a variety of bodily functions, most importantly the function of cardiovascular system (Tibenska et al., 2010) (Tibenska \& Medekova, 2014). Adequate physical

*E-mail:radik1@uniba.sk

๑) European Pharmaceutical Journal 
activity has positive impact on the cardiovascular system, such as prevention of heart disease (Myers, 2003) or physiological hypertrophy (Woodiwiss et al., 2000). It can also increase oxidative stress (Powers \& Jackson, 2008) or cause sudden death in athletes with underlying heart condition (Finocchiaro et al., 2016). Heart damage manifests itself by shift in major myosin heavy chain gene expression - decrease of alpha isoform (Myh6) and increase of beta isoform (Myh7) (Lowes et al., 1997). Chemical gonadectomy promotes in vivo and ex vivo cardiac dysfunction in sedentary rats associated with Myh7 upregulation, but voluntary wheel running provided protection from this process (Hydock et al., 2007). In case of heart damage in sports, focus is primary on the left ventricle, as main circulatory blood ejection component (Baggish \& Wood, 2011), but undetected right ventricle impairment can precede left ventricle damage (de Groote, 2016).

\section{METHODS}

\section{Experimental Design}

In the 8-week long experiment, 10-12 weeks old male Wistar rats were administered testosterone depot (Agovirin Depot $25 \mathrm{mg} / \mathrm{ml}$, BB Pharma a.s., (zech Republic) in dose of 100 $\mathrm{mg} / \mathrm{kg}$ (TES, $\mathrm{n}=15$ ) or vehiculum (CON, $\mathrm{n}=12$ ) once a week subcutaneously. Other groups were injected with the same dose of testosterone depot (SPOTES, $n=12$ ) or vehiculum (SPO, $\mathrm{n}=12$ ) and were running in exercise wheels ad libitum. Animals were sacrificed by $\mathrm{CO}_{2}$ asphyxiation and tissue samples were obtained from left and right ventricles of the heart.

\section{Gene expression}

Total RNA was isolated from samples of left and right ventricles of the heart using Tri-Reagent (Sigma-Aldrich, USA). We verified the quality of total RNA by $2 \%$ agarose gel electrophoresis and the quantity by spectrophotometry. Subsequently, total RNA was reverse-transcribed to cDNA (High-Capacity CDNA Reverse Transcription Kit, Applied Biosystems, USA), and realtime polymerase chain reaction (PCR) was performed using SYBR Green detection (qPCR kit SYBR Select Master Mix, Life Technologies, USA) on StepOnePlus ${ }^{\text {TM }}$ Real-Time PCR System (Life Technologies, USA) according to the manufacturer's instructions. Expression of Myh6 (myosin heavy chain 6, alpha), Myh7 (myosin heavy chain 7, beta) and Cybb (cytochrome b-245, beta polypeptide) was determined using the gene-specific primers. The following primer sequences were used: Myh6 (forward: „GCCCTTTGACATCCGCACAGAGT" reverse:"TCTGCTGCATCACCTGGTCCTCC"), Myh7 (forward: "GCGGACATTGCCGAGTCCCAG" reverse: "GCTCCAGGTCTCAGGGCTTCACA"), Cybb (forward: "TGGGAGACTGGACTGAGGGGCTA" reverse: „GGCTGTACCAAAGGGCCCATCAA"). B2m (beta2-microglobulin) and Hprt1 (hypoxanthine phosphoribosyltransferase 1) were used as endogenous reference genes. All primers were verified to yield a single PCR product with the correct molecular weight, and the absence of signal was confirmed when reverse transcription was omitted.

\section{Statistical analysis}

All variables are reported as mean \pm standard deviation (SD). Mean PCR efficiency estimates (E) per amplicon and quantification cycle $(\mathrm{Cq})$ values per sample were determined using LinRegPCR software (Ruijter et al., 2009, version 2015.0) and efficiency corrected relative expression ratios were calculated (all reactions had $\mathrm{E}>1.8$ and $\mathrm{Cq}<35$ ). The Shapiro-Wilk test was used to determine the normality of data. Normally distributed data (parametrical) were tested by analysis of variance (ANOVA) with post-hoc Tukey's honest significant difference tests. Non-parametrical data were tested by using the Kruskal-Wallis test with posthoc Wilcoxon test and Benjamini-Hochberg correction for multiple comparisons. Results with $p<0.05$ were considered as statistically significant. The data were handled by GraphPad Prism (GraphPad Software, Inc., version 6), R programming language and software environment for statistical computing and graphics (R Foundation for Statistical Computing, version 3.2.4) and Microsoft Excel (Microsoft, version 15.20).

\section{RESULTS}

We observed no statistically significant difference in gene expressions of Myh6 and Myh7 in both left and right ventricles of the study groups (data not shown). However, after percentage calculation by formula Myh6 \% = Myh6/ (Myh6+Myh7), we observed a mild but significant increase in percentage of Myh6 in left ventricles of testosterone groups ( ${ }^{*} p<0.05$ ) (Fig. 1). Higher expression of Cybb was also observed in the same compartment and study groups ( ${ }^{*} p<$ 0.05) (Fig. 2). No significant changes were observed in right ventricles. Voluntary, mild physical activity did not have a substantial effect on the measured results.

\section{DISCUSSION}

Supraphysiological doses of testosterone have deleterious effects on heart function in cases of abuse such as doping (Emer et al., 2016), but improvement of heart function was observed during testosterone replacement therapy for hypogonadism (Pongkan et al., 2015) and heart failure (Pugh et al., 2004). Our results indicate possible beneficial effect of supraphysiological doses of testosterone in healthy male rats, as cardiac myosin heavy chain gene expression shift in favour of Myh6 isoform may increase cardiac output, which is important in situations of increased demand (Lowes et al., 1997; Hydock et al., 2007). This change was accompanied by increased expression of oxidativestress-related gene Cybb, which corresponds with findings of Emer et al. (2016). Increased physical activity was described as 


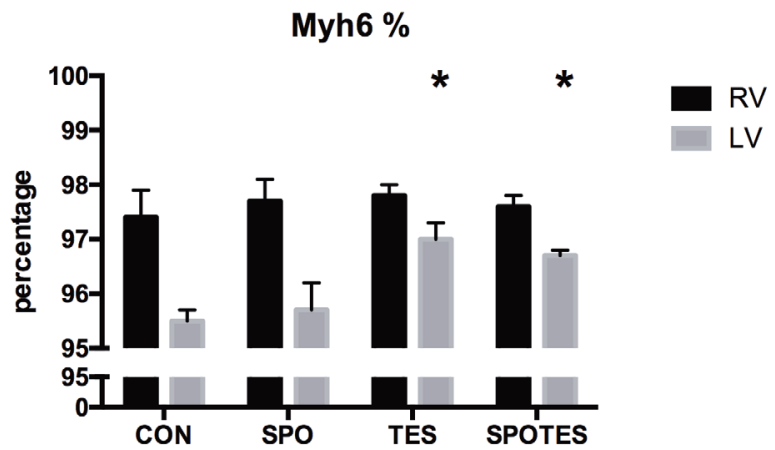

Figure 1. Percentage of Myh6 in right and left ventride of the heart. average $\pm S D ;{ }^{*} p<0.05$ vs. CON

impairing factor in heart function (Finocchiaro et al., 2016) and cause of increased oxidative stress (Powers \& Jackson, 2008), but in adequate amount and intensity showed cardioprotective effects (Myers, 2003). Rats in our experiment have shown no impairment of heart function on molecular level, according to the knowledge of Myh6 percentage as an important factor in the determination of cardiac output (Korte et al., 2005); on the contrary, it had tendency to improve. Major cardiac myosin heavy chains are known to be expressed approximately uniformly in both heart ventricles with greater than $95 \%$ in rats (Zammit et al., 2000). Although gene expressions were in general higher in the right ventricle compared to the left ventricle, recorded differences manifested in the left ventricle

\section{References}

[1] Altamirano F, Oyarce C, Silva P, Toyos M, Wilson C, Lavandero S, et al. Testosterone induces cardiomyocyte hypertrophy through mammalian target of rapamycin complex 1 pathway. Journal of Endocrinology 2009;202:299-307.

[2] Baggish AL and Wood MJ. Athlete's Heart and Cardiovascular Care of the Athlete: Scientific and Clinical Update. Circulation 2011;123:2723-2735.

[3] Emer E, Yildiz O, Seyrek M, Demirkol S, Topal T, Kurt B, et al. High-dose testosterone and dehydroepiandrosterone induce cardiotoxicity in rats: Assessment of echocardiographic, morphologic, and oxidative stress parameters. Human and Experimental Toxicology 2016;Vol. 35(5): 562-572.

[4] Finocchiaro G, Papadakis M, Robertus JL, et al. Etiology of Sudden Death in Sports. Journal of the American College of Cardiology 2016;67:2108-2115.

[5] de Groote P. Right ventricular systolic function in heart failure: A long story but still the same question. Archives of Cardiovascular Diseases 2016;109: 227-230.

[6] Hydock DS, Lien CY, Schneider CM, Hayward R. Effects of voluntary wheel running on cardiac function and myosin heavy chain in chemically gonadectomized rats. Am J Physiol Heart Circ Physiol 2007;293:H3254-H3264.

[7] Korte FS, Herron TJ, Rovetto MJ, McDonald KS. Power output is linearly related to MyHC content in rat skinned myocytes and isolated working hearts. Am J Physiol Heart Circ Physiol 2005;289:H801-H812.

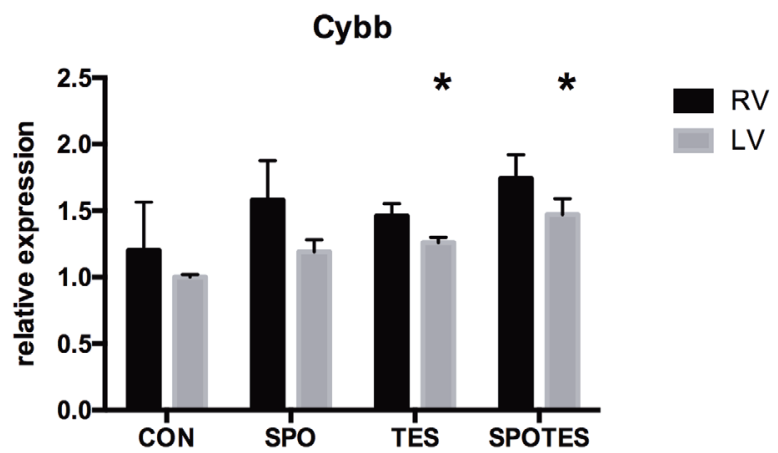

Figure 2. Percentage of $\mathrm{Cybb}$ in right and left ventride of the heart. average $\pm S D ;{ }^{*} p<0.05$ vs. CON

only, which is known to be a source and primary focus in case of heart damage in sports (Baggish \& Wood, 2011). However, physical activity did not have a significant effect on measured parameters. Supraphysiological doses of testosterone altered gene expression of contractile apparatus and oxidative stress in left, but not in right, ventricle of the heart.

\section{ACKNOWLEDGEMENT}

This work was supported by grants VEGA 1/0294/15 and APVV-0887-11 Molecular aspects of drug induced heart failure and ventricular arrhythmias from the Slovak Research and Development Agency.

[8] LowesBD,MinobeW,AbrahamWT,etal.Changesingeneexpression in the intact human heart. Downregulation of alpha-myosin heavy chain in hypertrophied, failing ventricular myocardium. J Clin Invest 1997;100(9):2315-24.

[9] Myers J. Exercise and Cardiovascular Health. Circulation 2003;107:e2-e5.

[10] Pongkan W, Chattipakorn SC and Chattipakorn N. Chronic Testosterone Replacement Exerts Cardioprotection against Cardiac Ischemia-Reperfusion Injury by Attenuating Mitochondrial Dysfunction in Testosterone-Deprived Rats. PLoS ONE 2015;10(3):e0122503.

[11] Powers SK and Jackson MJ. Exercise-Induced Oxidative Stress: Cellular Mechanisms and Impact on Muscle Force Production. Physiol Rev 2008;88(4):1243-12764.

[12] Pugh PJ, Jones RD, West JN, Jones TH, Channer KS. Testosterone treatment for men with chronic heart failure. Heart 2004;90:446447.

[13] Tibenska M, Kyselovicova O, Medekova H. Anthropometric and functional changes and their relationship after two-year aerobic gymnastics training. Acta Fac Pharm Univ Comen 2010;LVII:1-7.

[14] Tibenska M, Medekova H. "Z"-scores of anthropometric and motor parameters of girls in aerobic gymnastics. Acta Fac Pharm Univ Comen 2014;LXI(2):55-58.

[15] Woodiwiss AJ, Trifunovic B, Philippides M, Norton GR. Effects of an androgenic steroid on exercise-induced cardiac remodeling in rats. J Appl Physiol 2000;88:409-415. 
Eur. Pharm. J. LXIII, 2016 (1): 12-15.

Voluntary exercise and testosterone therapy caused increase in percentage of Myh6 and ...

[16] Zammit PS, Kelly RG, Franco D, Brown N, Moorman AFM, Buckingham ME. Suppression of Atrial Myosin Gene Expression Occurs Independently in the Left and Right Ventricles of the Developing Mouse Heart. Dev Dyn 2000;217:75-85. 